\title{
Functional Traits on Cavity-nesting Birds in Subtropical Andean Forest: Response to Logging Activity and Comparing with American Temperate Forests
}

\section{Alejandro A. Schaaf ( $\sim$ schaaf.alejandro@gmail.com )}

Instituto de Ecorregiones Andinas (INECOA), Universidad Nacional de Jujuy - Centro Científico Tecnológico CONICET Salta-Jujuy, Av. Bolivia 1239, 4600 San Salvador de Jujuy, Jujuy, Argentina Daniela Gomez

Instituto de Ecorregiones Andinas (INECOA), Universidad Nacional de Jujuy - Centro Científico Tecnológico CONICET Salta-Jujuy, Av. Bolivia 1239, 4600 San Salvador de Jujuy, Jujuy, Argentina Ever Tallei

Biología de Aves, Instituto Argentino de Investigaciones de las Zonas Áridas (IADIZA), Centro Científico Tecnológico CONICET - Mendoza, Av. Ruiz Leal s/n, Parque General San Martin, 5500 Mendoza, Arge

Constanza G. Vivanco

Instituto de Ecorregiones Andinas (INECOA), Universidad Nacional de Jujuy - Centro Científico Tecnológico CONICET Salta-Jujuy, Av. Bolivia 1239, 4600 San Salvador de Jujuy, Jujuy, Argentina

\section{Román A. Ruggera}

Instituto de Ecorregiones Andinas (INECOA), Universidad Nacional de Jujuy - Centro Científico Tecnológico CONICET Salta-Jujuy, Av. Bolivia 1239, 4600 San Salvador de Jujuy, Jujuy, Argentina

\section{Research Article}

Keywords: Functional Traits, Cavity-nesting Birds, Subtropical Andean Forest, American Temperate Forests

Posted Date: May 27th, 2021

DOl: https://doi.org/10.21203/rs.3.rs-555302/v1

License: (a) (i) This work is licensed under a Creative Commons Attribution 4.0 International License. Read Full License 


\section{Abstract}

Logging causes changes in habitat structure, which can potentially lead to variations in taxonomic and functional richness of biodiversity. In this paper, we examined how logging in subtropical Andean forests has influenced taxonomic and functional diversity of cavity-nesting birds. We used point-counts to examine the effects of logging on taxonomic and functional traits of avian communities (Functional Richness, Functional evenness, Functional Divergence, and Community-weighted mean). We found that logging changes bird richness and abundance, although it had no effect on the functional response to the measured traits. The comparison of our results with those of temperate forests of Canada and Chile reveals differences in the functional richness, with a lower impact of logging on functional traits. We highlight the importance of including functional traits in the analyses, since the reduction in the species richness and abundance may not translate into functional changes within the ecosystem.

\section{Introduction}

When logging is conducted, the extraction of different tree species changes the availability of food and nesting resources for bird species 1,2 . In general, logging leads to an increase in the abundance of widely distributed bird species with low resource use specificity (e.g. feeding or nesting)3,4. Other bird species may respond negatively to these changes by affecting their occurrence or decreasing their abundance5,6,7,8. Current evidence in tropical and subtropical forests indicates that cavity nesting birds are one of the most sensitive groups to forest exploitation7,9,10,11,12. Logging may remove trees essential for reproduction of cavity-nesting birds, since certain species using trees with certain specific features (e.g size, cavity depth, tree species)13,14. For example, large secondary cavity nesting bird species (such as ducks, parrots and toucans) depend on trees with an appropriate entrance size and depth for nesting, which can be scarce or absent in logged forests13,15,16. For woodpeckers, habitat alteration can lead to difficulties in the use of substrates suitable for excavation 17,18 . This situation may increase competence in the exploration of available trees, reducing the abundance of these birds6,19,20. It should be noted in this context that many of these species play an important role as pest controllers (e.g. owls and raptors) or seed dispersers (e.g. toucans); therefore, the diversity and abundance of this species play an important role in the persistence of the ecosystem services in the forest4,9,21,22. Traditional taxonomic indices analysed changes in communities' diversity. Nowadays these indices are complemented with functional diversity indices which describe how different species traits respond to ecosystem changes22,23,24,25,26. For birds, these indices have often been based on morphological (e.g. body mass) and ecological traits (e.g. trophic guilds, seed dispersal, pest control)27,28,29. For example, species richness may increase or remain unchanged in response to environmental disturbance, whereas functional diversity can be sensitive to these changes $23,24,26$. This may occur because in disturbed environments there may be a replacement or decline of habitat-specialist species, with a consequent increase of generalist species29,30. There may also be species capable of maintaining the system stabilized, although the loss of these species above a certain threshold can impair the ecosystem processes (e.g seed dispersal, pest control)31. Thus, measuring functional traits is important and 
necessary to obtain an idea about the effect of environmental perturbation32,33. Especially for cavity nesting birds, studies on the way that logging forest affect the functional diversity was conducted in temperate forests of North and South America. The results showed that although some species can persist in these habitats their ecosystemic functions may be severely affected22. Therefore is important to carry out studies that analyze the effect of forest exploitation on taxonomic and functional diversity in cavity-nesting birds in template and subtropical forests in America. On the other hand, it would be interesting comparing these studies with other conducted in temperate forest, in order to establish how logging affects ecosystem functions and the persistence of populations and communities of these birds over the time34,35. Therefore, the aim of this study is to assess taxonomic and functional diversity of cavity-nesting birds at both logged and unlogged Andean subtropical forests of northwestern Argentina. Specifically, in this forest of northwestern Argentina, previous research reported a decrease in the abundance of cavity-nesting birds at logging sites7,36. Moreover, Schaaf et al. (2020a) found a decrease in some parameters of tree functional diversity (e.g size tree, cavity entrance area) available for cavitynesting birds; but no specifically on the effects of functional traits of cavity-nesting birds. Due to the impact of logging on avian cavity nesters, we will expect lower taxonomic richness and functional diversity of these bird species in disturbed sites; comparing our results with those reported in American temperate forest, and observing if ecosystemic functions of this bird group in subtropicals forest behaves to logging in the same way that in template forests.

\section{Methods}

\section{Study area.}

This study took place in the Andean rainforest of northwestern Argentina, which belongs to the seasonally dry forests of South America located between 400 and $900 \mathrm{~m}$ a.s.l. ${ }^{37}$. The climate is highly seasonal with an annual rainfall between 800 and $1000 \mathrm{~mm}$, concentrated from November to February ${ }^{38}$. This forest is characterized by the presence of tree species: Calycophylum multiflorum, Phyllostylon rhamnoides, Myroxylon peruiferum, Amburana cearensis, and Cedrela angustifolia. Over the years, timber extraction in piedmont forests has been mainly focused in 10 tree species: Cedrela balansae, A. cearensis, Anadenanthera colubrina, C. multiflorum, P. rhamnoides, Myracrodruon urundeuva, Tabebuia avellanedae, Myroxylon peruiferum, Cordia trichotoma, and Pterogyne nitens. The abundance of these species has been widely reduced in logged sites $^{39,40,41}$.

\section{Fieldwork}

Field sampling was carried out in six sites, three of which have not been logged for more than 45 years, and three with ongoing logging activity, which were grouped treatments as 'unlogged' and 'logged' sites, respectively, for statistical analyses (Fig. 1). At each site, we delimited an area of 100 ha. Habitat characterization was performed using between 20 and 30 vegetation plots per site where we measured: diameter at the breast height (DBH), tree density (ind/ha, of trees with $\mathrm{DBH}>10 \mathrm{~cm}$ ), basal area, tree 
height, as well as the density, DBH, cavity and tree heights of trees with cavities (considered trees with available cavities for secondary cavity-nesting birds). Treatments were compared with the Wilcoxon (Mann-Whitney, W) non-parametric test. We used the software Infostat with a significance level of $0.05^{42}$.

\section{Bird survey}

Bird record was performed through 86 point-counts in logged and unlogged sites (27-30 points per site) during two breeding seasons: October to January of 2015-2016 and 2016-2017 (Total: 162 pointscounts). Point counts on consecutive seasons helped us to reduce possible bias in species detection and to average the values of both breeding periods ${ }^{7,43}$. We performed the point-counts every $150-200 \mathrm{~m}^{44}$, recording every cavity-nesting bird species seen or heard within a $50 \mathrm{~m}$ radius for $10 \mathrm{~min}$ between 07:00 and 11:00 am. We waited for 5 min between successive point-counts and we avoided sampling during unfavorable weather conditions.

\section{Taxonomic and functional diversity analyses}

We estimated species richness (measured as the number of species) and abundance of cavity-nesting birds in each treatment (unlogged and logged forest).

Functional traits associated with cavity-nesting birds included categorical (nesting guild, trophic guild, and foraging substrate) and continuous traits (body mass and nest-tree size) (Table 1) $22,45,46,47$. The nesting guild was divided into three categories: strong excavators (woodpeckers), weak excavators (trogons), and secondary-cavity nesters ${ }^{22}$. The trophic guild was divided into four categories: frugivoreinsectivore, granivore, insectivore and omnivore ${ }^{48,49}$. Foraging substrate contained six categories: canopy, understory, ground, all forest strata, bark, and air $^{22,48}$. Body masses were obtained from del Hoyo et al. (1992), averaging each species and sex minimum and maximum values. On the other hand, traits on nest-tree size were obtained in the field during the intense nest searching performed at the same sites $^{21,47}$. 
Table 1

Trait values used to measure functional diversity parameters for avian cavity-nesting species from subtropical piedmont forests in Argentina. Nesting guild: secondary-cavity nesters (S), weak cavity excavators (WE) y strong primary excavator (E). Foraging guild: insectivore (I), frugivore-insectivore (FI), granivore $(G)$, omnivore $(O)$. Foraging substrate: air $(A)$, Bark $(X)$, Canopy $(C)$, Understory $(U)$. ** registered only in unlogged forest; * registered only in logged forest.

\begin{tabular}{|c|c|c|c|c|c|c|}
\hline English name & Scientific name & $\begin{array}{l}\text { Nesting } \\
\text { guild }\end{array}$ & $\begin{array}{l}\text { Foraging } \\
\text { guild }\end{array}$ & $\begin{array}{l}\text { Foraging } \\
\text { substrate }\end{array}$ & $\begin{array}{l}\text { Nest-tree } \\
\text { size (DBH, } \\
\mathrm{cm})\end{array}$ & $\begin{array}{l}\text { Body } \\
\text { mass } \\
\text { (mean g) }\end{array}$ \\
\hline $\begin{array}{l}\text { American } \\
\text { Kestrel }\end{array}$ & $\begin{array}{l}\text { Falco } \\
\text { sparverius* }\end{array}$ & $S$ & 1 & A & 62.6 & 122.5 \\
\hline $\begin{array}{l}\text { Black-banded } \\
\text { Woodcreeper }\end{array}$ & $\begin{array}{l}\text { Dendrocolaptes } \\
\text { picumnus }\end{array}$ & $S$ & 1 & $x$ & 57.32 & 82.5 \\
\hline $\begin{array}{l}\text { Blue-crowned } \\
\text { Trogon }\end{array}$ & Trogon curucui & WE & $\mathrm{FI}$ & C & 59.75 & 51 \\
\hline $\begin{array}{l}\text { Brown-crested } \\
\text { Flycatcher }\end{array}$ & $\begin{array}{l}\text { Myiarchus } \\
\text { tyrannulus }\end{array}$ & $S$ & 1 & $\mathrm{X}$ & 35.51 & 29 \\
\hline $\begin{array}{l}\text { Buff-browed } \\
\text { Foliage-gleaner }\end{array}$ & $\begin{array}{l}\text { Syndactyla } \\
\text { rufosuperciliata }\end{array}$ & S & 1 & $\mathrm{x}$ & 57.32 & 27.5 \\
\hline $\begin{array}{l}\text { Cream-backed } \\
\text { Woodpecker }\end{array}$ & $\begin{array}{l}\text { Campephilus } \\
\text { leucopogon }\end{array}$ & E & 1 & C & 56.19 & 242 \\
\hline $\begin{array}{l}\text { Dot-fronted } \\
\text { Woodpecker }\end{array}$ & $\begin{array}{l}\text { Veniliornis } \\
\text { frontalis }\end{array}$ & E & 1 & U & 42.34 & 35 \\
\hline $\begin{array}{l}\text { Dusky-capped } \\
\text { Flycatcher }\end{array}$ & $\begin{array}{l}\text { Myiarchus } \\
\text { tuberculifer }\end{array}$ & S & 1 & $X$ & 35.51 & 21.7 \\
\hline $\begin{array}{l}\text { Golden-olive } \\
\text { Woodpecker }\end{array}$ & $\begin{array}{l}\text { Piculus } \\
\text { rubiginosus** }\end{array}$ & E & 1 & C & 46.78 & 59.5 \\
\hline $\begin{array}{l}\text { Great Rufous } \\
\text { Woodcreeper }\end{array}$ & $\begin{array}{l}\text { Xiphocolaptes } \\
\text { major }\end{array}$ & S & 1 & $x$ & 35 & 141 \\
\hline $\begin{array}{l}\text { Green-cheeked } \\
\text { Parakeet }\end{array}$ & $\begin{array}{l}\text { Pyrrhura } \\
\text { molinae }\end{array}$ & $S$ & $\mathrm{G}$ & C & 41.17 & 71.5 \\
\hline $\begin{array}{l}\text { Narrow-billed } \\
\text { Woodcreeper }\end{array}$ & $\begin{array}{l}\text { Lepidocolaptes } \\
\text { angustirostris }\end{array}$ & S & I & $x$ & 52.57 & 29.5 \\
\hline $\begin{array}{l}\text { Olivaceous } \\
\text { Woodcreeper }\end{array}$ & $\begin{array}{l}\text { Sittasomus } \\
\text { griseicapillus }\end{array}$ & $S$ & 1 & $x$ & 57.32 & 14 \\
\hline $\begin{array}{l}\text { Rufous } \\
\text { Casiornis }\end{array}$ & Casiornis rufus & S & I & $x$ & 35.51 & 24.5 \\
\hline $\begin{array}{l}\text { Scaly-headed } \\
\text { Parrot }\end{array}$ & $\begin{array}{l}\text { Pionus } \\
\text { maximiliani }\end{array}$ & S & $G$ & C & 60.41 & 263 \\
\hline $\begin{array}{l}\text { Streaked } \\
\text { Flycatcher }\end{array}$ & $\begin{array}{l}\text { Myiodynastes } \\
\text { maculatus }\end{array}$ & S & I & C & 53.88 & 43.5 \\
\hline
\end{tabular}




\begin{tabular}{|lllllll|}
\hline English name & Scientific name & $\begin{array}{l}\text { Nesting } \\
\text { guild }\end{array}$ & $\begin{array}{l}\text { Foraging } \\
\text { guild }\end{array}$ & $\begin{array}{l}\text { Foraging } \\
\text { substrate }\end{array}$ & $\begin{array}{l}\text { Nest-tree } \\
\text { size (DBH, } \\
\text { cm) }\end{array}$ & $\begin{array}{l}\text { Body } \\
\text { mass } \\
\text { (mean g) }\end{array}$ \\
\hline Swainson & $\begin{array}{l}\text { Myiarchus } \\
\text { swainsoni }\end{array}$ & S & I & U & 35.51 & 25.1 \\
\hline Toco Toucan & $\begin{array}{l}\text { Ramphastos } \\
\text { toco }\end{array}$ & S & O & C & 68.28 & 680 \\
\hline $\begin{array}{l}\text { Turquoise- } \\
\text { fronted Parrot }\end{array}$ & $\begin{array}{l}\text { Amazona } \\
\text { aestiva }\end{array}$ & S & G & C & 44.39 & 400 \\
\hline $\begin{array}{l}\text { White-barred } \\
\text { Piculet }\end{array}$ & $\begin{array}{l}\text { Picumnus } \\
\text { cirratus }\end{array}$ & S & I & U & 44.95 & 9.15 \\
\hline $\begin{array}{l}\text { White-eyed } \\
\text { Parakeet }\end{array}$ & $\begin{array}{l}\text { Aratinga } \\
\text { leucophthalma }\end{array}$ & S & G & C & 71.62 & 159 \\
\hline $\begin{array}{l}\text { Yellow-collared } \\
\text { Macaw }\end{array}$ & $\begin{array}{l}\text { Primolius } \\
\text { auricollis }\end{array}$ & S & G & C & 52.54 & 245 \\
\hline
\end{tabular}

The functional diversity parameters included: Functional Richness (FRic), which represents the multivariate space filled by the functional traits of bird species present, regardless the relative abundance of bird species; Functional Evenness (FEve), represents the degree to which bird trait values are regularly distributed according to their abundance; and Functional Divergence (FDiv), which indicates the proximity of the most frequent functional trait values in the avian community. FRic and FDiv have not upper limits, whereas FEve vary between 0 and $1^{33,51}$. We also estimated the Community-Weighted mean (CWM), defined as the average of trait values in the community, weighted by the relative abundance of the species carrying each value, for body mass and nest-tree $\mathrm{DBH}^{22,33,51}$.

After standardization of traits, we estimated the functional diversity parameters for each treatment (logged and unlogged) in $\mathrm{R}^{52}$, using the dbFD function in package ' $\mathrm{FD}^{\prime 32,53}$. The taxonomic and functional diversity parameters were compared between treatments employing ANOVA and the TukeyHSD posthoc test (F). Graphs were produced in InfoStat ${ }^{42}$.

Finally, we compared the results obtained by Ibarra et al. (2017), for temperate forests of Canada and Chile with clearcutting (the authors also included partial logging) in order to compare different American forests.

\section{Results}

Site characteristics. In unlogged forests, we registered 54 tree species, and 22 of them had decay-formed cavities; in logged sites we found 42 tree species, and 16 of them had decay-formed cavities. Averaged variables values (total trees/ha, basal area, DBH, and tree height) and dominant tree species are detailed in Fig. 1 and tables S1, S2 (supplementary material), respectively. 
Avian taxonomic diversity. A total of 1673 individuals from 22 cavity-nesting bird species were recorded across the two breeding seasons. We registered 21 bird species at unlogged sites and 21 in sites with ongoing logging sites. Species richness $(F=46.26 ; p<0.001)$ and abundance $(F=64.55 ; p<0.001)$ per point-count were significantly higher at unlogged sites (Fig. 2).

Functional diversity. We found no significant differences in functional richness $(F=4.50 ; p=0.101)$ or functional divergence $(F=3.63 ; p=0.129)$, but we did found differences in functional evenness $(F=10.77$; $p=0.03$, which resulted higher in logging sites. The Community-Weighted Mean (CWM) showed no statistical difference for body mass $(F=0.01 ; p=0.936)$ or nest-tree size $(F=0.11 ; p=0.756)(F i g .2$, and Table S3 supplementary material).

Taxonomic and functional diversity in Temperate and Subtropical forests. Our results were partially similar to those reported for temperate forests (Fig. 2; Ibarra et al. (2017). In Canada, no differences were found in species richness between logged and unlogged sites, whereas Chile presented significant differences between treatments. Functional richness values in temperate forests were lower than ours, and close to 0 , with differences between treatments. Functional evenness, on the other hand, was similar in temperate and subtropical environments; although here we found significant differences regarding both treatments (logging sites presented higher values). Similar values of functional divergence were also found in the three environments, but treatments in Chile were different, being higher in unlogged forest sites. CWM-body mass, however, turned out to be lower in temperate forests and higher in unlogged forests when compared to logging treatment. CWM-nest tree size between treatments was significantly different only in temperate forests of Chile. In addition, this parameter was lower in Canada (close to 30 $\mathrm{cm}$ ) compared to Chilean temperate forests and Argentinian subtropical forests, in which values exceeded $50 \mathrm{~cm}$ (Fig. 2, and Table S3 supplementary material).

\section{Discussion}

Our results indicate that logging practices affect the richness and abundance of cavity nesting birds, but maintains the species composition. Research conducted in other temperate and subtropical environments $4,7,22,54$ have reported a decrease in richness and abundance of these birds in logged forest mainly due to changes in forest structure (e.g understory and canopy), food availability and suitable nesting sites. This decrease may be explained by the low availability of nesting cavities ${ }^{7}$. In addition, in these subtropical forests logging has negatively affected the nest survival of cavity-nesting birds (unpublished data). This may also explained the decrease in the abundance of both, excavators and secondary-cavity nesters.

We found that changes in species richness between treatments (unlogged vs logged) did not affect functional diversity. This indicates that changes in taxonomic richness caused by anthropogenic disturbances do not necessarily translate into changes in functional richness ${ }^{23,24}$ thus, showing that available ecological niches (e.g trees available for nesting) are being well exploited ${ }^{51}$. Avian cavity nesters in the studied forests have, therefore, similar ecological functions with equally defined ecological 
traits $^{23,55}$. Our FRic results differ from the ones reported for the temperate forests of Canada and Chile, where this parameter was found to be lower at logged sites, causing a decrease in the amount of functional niche volume filled by these bird species ${ }^{22}$. Besides, in these forests FRic values were closer to 0 , indicating that the available ecological niches are less explored and colonized by habitat generalist and opportunistic bird species ${ }^{22,51}$.

Higher Functional Evenness (FEve) values at logged sites, may be linked to habitat change and low tree availability, where birds are exploring new functional niches to reproduce and feed (Mason et al. 2005; Villéger et al. 2010). In temperate forests no differences were found in FEve between logged and unlogged forests, also indicating that the functional niche volume filled by bird species can be relatively resistant to tree removal ${ }^{22,33,46}$.

Functional divergence (FDiv) was not significantly different between treatments, therefore subtropical forests lack birds with dominant functional traits ${ }^{22,51}$. The same results were obtained for Canadian temperate forests, whilst in Chile, this parameter was significantly higher in unlogged sites. In temperate forests of South America, thus, logging practices may cause differentiation of functional traits in bird species $^{22,33,51}$.

The community weighted mean (CWM) for body mass presented no differences between treatments. This reveals that despite the lower species richness and abundance, the species composition and body mass are maintained $33,51,56$. In contrast to our finding, temperate forests presented significant differences between treatments, and lower bird body mass $(\approx 30-50 \mathrm{~g}$ in temperate and $\approx 100-110 \mathrm{~g}$ in subtropical forests). Despite the higher body mass of cavity nesters in subtropical forests, species are not excluded and this variable remains constant ${ }^{22}$, which may be explained by habitat type. Subtropical forests have a higher diversity of tree species available for nesting and foraging, thus, decreasing competition and maintaining bigger species ${ }^{46,57}$. CWM for nest-tree size used by birds also appeared to be unaffected between treatments. This result possibly relates to bird usage of high tree species for nesting ( $\mathrm{DBH}>50$ $\mathrm{cm}$ ) despite the lower availability of trees thus, decreasing the exploration of this treat ${ }^{47}$. Similar results were found in Canada, but not in Chile, where significant differences were reported. In Chile, trees used for nesting had higher DBH values in unlogged sites, whereas in Canada, birds used trees of similar size in both treatments. This explains that birds are using trees of similar size in both logged and unlogged sites in temperate forests of North America and subtropical forests of Argentina ${ }^{22}$.

\section{Conclusion}

Based on the results reported here, logging practices lead to changes in the richness and abundance of cavity nesting birds, but maintain the response of the functional traits measured. This may indicate that the level of timber extraction changes the species richness but not the composition or function of these birds and, also, that the ecological niches (e.g nesting trees) are being well explored in disturbed sites. This is an interesting finding since the analysis of the richness and functional traits of trees available for 
secondary-cavity nesters (e.g. DBH, cavity height) ${ }^{36}$ showed lower values in logged sites. Thus, despite the lower availability of tree species and the significant differences in the functional diversity of cavity trees, only trees with distinctive traits (such as $\mathrm{DBH}>50 \mathrm{~cm}$ ) are used in both sites, logged and unlogged. This finding is relevant for the management and conservation of logging sites in subtropical forests, which should consider the retention of large trees.

The functional differences reported for temperate forests may be caused by the presence of more specialized species. In Canada, for example, secondary-cavity nesters depend mostly on cavities created by woodpeckers, whereas in Chile, they depend on large, decomposing trees, which are generally removed in logging sites ${ }^{22}$. In subtropical forests, however, these bird species use cavities generated by tree decay processes in different species of living trees ${ }^{21,47}$. This may allow birds to have more niches available for exploration, even in logged sites.

Finally, we highlight the importance of incorporating functional analyses under different forest disturbances, since changes in taxonomic richness do not always translate into changes in functional traits $^{24}$ and, these analyses help us clarify the mechanisms and relationships between taxonomic richness and the ecosystem functions ${ }^{51}$.

\section{Declarations}

\section{Acknowledgments}

We thank the assistants involved in the fieldwork. We thank National Park Administration of Argentina for allowing us to work in Calilegua National Park. This study was funded by CONICET, Rufford small grant, Optic for the tropic, Bergstrom Award, and Idea Wild. AAS, DG, ET, and ET are postdoctoral fellows at CONICET; RAR is researchers at CONICET, Argentina.

\section{Author contributions statement}

A.A.S, E.T, CGV and R.A.R conceived the study and conducted the fieldwork; D.G analyzed data. All authors reviewed the manuscript.

\section{Competing Interests}

The authors declare that they have no competing interests.

\section{References}

1. Tews, J. et al. Animal species diversity driven by habitat heterogeneity/diversity: the importance of keystone structures. J. biogeogr . 31, 79-92 (2004). 2. Robles, H. et al. Sylvopastoral management and 
conservation of the middle spotted woodpecker at the south-western edge of its distribution range. For. Ecol. Manag. 242, 343-352 (2007). 3. Aleixo, A. Effects of selective logging on a bird community in the Brazilian Atlantic Forest. Condor 101, 537-548 (1999). 4. Robles, H., Carlos Ciudad, C. \& Matthysen, E. Tree-cavity occurrence, cavity occupation and reproductive performance of secondary cavity-nesting birds in oak forests: The role of traditional management practices. For. Ecol. Manag. 261, 1428-1435 (2011). 5. Wiebe, K. L. Nest sites as limiting resources for cavity-nesting birds in mature forest ecosystems: a review of the evidence. J. Field Ornithol. 82, 239-248 (2011). 6. Politi, N., Hunter, M. \& Rivera, L. Assessing the effects of selective logging on birds in Neotropical piedmont and cloud montane forests. Biodiver. Conserv. 21, 3131-3155 (2012). 7. Burivalova, Z. et al. Avian responses to selective logging shaped by species traits and logging practices. Proc. R. Soc. London B Biol. Sci. 282, 20150164 (2015). 8. Bergner, A. et al. Influences of forest type and habitat structure on bird assemblages of oak (Quercus spp.) and pine (Pinus spp.) stands in southwestern Turkey. For. Ecol. Manag. 336, 137-147 (2015). 9. Sekercioglu, C. $\mathrm{H}$. Effects of forestry practices on vegetation structure and bird community of Kibale National Park, Uganda. Biol. Conserv. 107, 229-240 (2002). 10. Stratford, J. A. \& Robinson W. D. Gulliver travels to the fragmented tropics: geographic variation in mechanisms of avian extinction. Front. Ecol. Environ. 3, 85-92 (2005). 11. Moore, R. P. et al. Experimental evidence for extreme dispersal limitation in tropical forest birds. Ecol. Lett. 11, 960-968 (2008). 12. Woltmann, S. Bird community responses to disturbance in a forestry concession in lowland Bolivia. Biodiv. Conserv. 12, 1921-1936 (2003). 13. Aitken, K. E. H. \& Martin, K. The importance of excavators in hole-nesting communities: availability and use of natural tree holes in old mixed forests of western Canada. J. Ornithol. 148, 425-434 (2007). 14. Strubbe, D. \& Matthysen, E. Experimental evidence for nest-site competition between invasive ring-necked parakeets (Psittacula krameri) and native nuthatches (Sitta europaea). Biol. Conserv. 142, 1588-1594 (2009). 15. Rivera, L., Politi, N. \& Bucher, H. E. Nesting habitat of the Tucuman Parrot Amazona tucumana in an oldgrowth cloud-forest of Argentina. Bird Conserv. Int. 22, 398-410 (2012). 16. Schaaf, A. A. et al. Cavity-tree use and frequency of response to playback by the Tropical Screech-Owl in northwestern Argentina. Neotrop. Biol. Conserv. 14, 99-107 (2019). 17. Li, P. \& Martin, T. E. Nest-site selection and nesting success of cavity-nesting birds in high elevation forest drainages. Auk 108, 405-418 (1991). 18. Schepps, J., Lohr, S. \& Martin, T. E. Does tree hardness influence nest-tree selection by primary cavity nesters? Auk 116, 658665 (1999). 19. Rudolph, D. C., Richard N. Conner, R. N. \& Turner, J. Competition for red-cockaded woodpecker roost and nest cavities: effects of resin age and entrance diameter. Wilson Bull. 102, 23-36 (1990). 20. Drever, M. C. \& Martin, K. Response of woodpeckers to changes in forest health and harvest: implications for conservation of avian biodiversity. For. Ecol. Manage. 259, 958-966 (2010). 21. Ruggera, R. A. et al. "Exploring nest webs in more detail to improve forest management." For. Ecol. Manag. 372, 93100 (2016). 22. Ibarra, J.T. et al. Maintaining ecosystem resilience: functional responses of tree cavity nesters to logging in temperate forests of the Americas. Sci. Rep. 7, 4467 (2017). 23. Hooper, D. U. et al. Effects of biodiversity on ecosystem functioning: a consensus of current knowledge. Ecol. Monogr. 75, 335 (2005). 24. Córdova-Tapia, F. \& Zambrano, L. La diversidad funcional en la ecología de comunidades. Ecosistemas 24, 78-87 (2015). 25. Leaver, J. et al. Response of bird functional diversity to forest product harvesting in the Eastern Cape, South Africa. For. Ecol. Manag. 445, 82-95 (2019). 26. Georgiev, K. B. et al. Salvage logging changes the taxonomic, phylogenetic and functional successional trajectories of forest 
bird communities. J. Appl. Ecol. 57, 1103-1112 (2020). 27. Negret, B. E. S. ed. La ecología funcional como aproximación al estudio, manejo y conservación de la biodiversidad: protocolos y aplicaciones. Editorial Instituto de Investigación de Recursos Biológicos Alexander von Humboldt, 2016. 28. Loreau, M., Naeem, S. \& Inchausti, P. Biodiversity and ecosystem functioning: synthesis and perspectives. (Oxford University Press, 2002). 29. Kassen, R. The experimental evolution of specialists, generalists, and the maintenance of diversity. J. Evol. Biol. 15, 173-190 (2002). 30. Devictor, V., Julliard, R. \& Jiguet, F. Distribution of specialist and generalist species along spatial gradients of habitat disturbance and fragmentation. Oikos 117, 507-514 (2008). 31. Scherer-Lorenzen, M. Biodiversity and ecosystem functioning: basic principles. Biodiversity: structure and function. (Encyclopedia of life support systems, 2005). 32. Laliberté, E. \& Legendre, P. A distance-based framework for measuring functional diversity from multiple traits. Ecology 91, 299-305 (2010). 33. Villéger, S., Mason, N. W. \& Mouillot, D. New multidimensional functional diversity indices for a multifaceted framework in functional ecology. Ecology 89, 2290-2301 (2008). 34. Lindenmayer, D. B., Margules, C. R. \& Botkin, D. B. Indicators of biodiversity for ecologically sustainable forest management. Conserv. Biol. 14, 941-950 (2020). 35. Gregory, R. D. et al. The generation and use of bird population indicators in Europe. Bird Conserv. Int. 18, S223-S244 (2008). 36. Schaaf, A. A. et al. Functional diversity of tree cavities for secondary cavity-nesting birds in logged subtropical Piedmont forests of the Andes. For. Ecol. Manag. 464, 118069 (2020). 37. Prado, D. E. Seasonally dry forests of tropical South America: from forgotten ecosystems to a new phytogeographic unit. Edinb. J. Bot. 57, 437461 (2000). 38. Arias, M. \& Bianchi, A. R. Estadísticas climatológicas de la Provincia de Salta. Dirección de Medio Ambiente y Recursos Naturales, Provincia de Salta, Estación Experimental Agropecuaria Salta, Inta, 1996. 39. Brown, A. D. \& Malizia, L. R. Las selvas pedemontanas de las Yungas. Ciencia hoy 14, $52-$ 63 (2004). 40. Politi, N., Hunter Jr., M. \& Rivera, L. Nest Selection by Cavity-nesting Birds in Subtropical Montane Forests of the Andes: Implications for Sustainable Forest Management. Biotropica 41, 354-360 (2009). 41. Politi, N., Hunter Jr., M. \& Rivera, L. Availability of cavities for avian cavity nesters in selectively logged subtropical montane forests of the Andes. For. Ecol. Manag. 260, 893-906 (2010). 42. Di Rienzo, J. A. et al. Software INFOSTAT Versión 2008. FCA, UNC. Córdoba, 2008. 43. Hill, D. et al. Handbook of biodiversity methods: survey, evaluation and monitoring. Cambridge University Press, Cambridge, 2005. 44. Ralph C. J., Droege, S. \& Sauer, J. R. Managing and monitoring birds using point counts: standards and applications. USDA, Albany, 1995. 45. Cockle, K. L., Martin, K. \& Wesołowski, T. (2011). Woodpeckers, decay, and the future of cavity-nesting vertebrate communities worldwide. Front. Ecol. Environ. 9, 377-382 (2011). 46. Ibarra, J. T. \& Martin, K. Biotic homogenization: loss of avian functional richness and habitat specialists in disturbed Andean temperate forests. Biol. Conserv. 192, 418-427 (2015). 47. Schaaf, A. A. et al. Identification of tree groups used by secondary cavity-nesting birds to simplify forest management in subtropical forests. J. For. Res. 31, 1417-1424 (2020). 48. Blendinger, P. G. \& Álvarez, M. E. Aves de la Selva Pedemontana de las Yungas australes. In Selva Pedemontana de las Yungas. Historia Natural, Ecología y Manejo de un Ecosistema en Peligro. (Eds AD Brown, A. D et al.) 233-272 (2009). 49. Wilman, $\mathrm{H}$. et al. EltonTraits 1.0: species-level foraging attributes of the world's birds and mammals. Ecology 95 , 2027-2027 (2014). 50. del Hoyo, J., Elliott, A., \& Sargatal, J. (1992). Handbook of the birds of the world (Vol. 1, No. 8). Barcelona: Lynx edicions. Del Hoyo, J. et al. Handbook of the birds of the world. (Lynx editions, 1992). 51. Mason, N. W. H., Mouillot, D., Lee, W. G. \& Wilson, J. B. Functional richness, functional 
evenness and functional divergence: the primary components of functional diversity. Oikos 111, 112-118 (2005). 52. R Core Team. R: a language and environment for statistical computing. R Foundation for Statistical Computing, Vienna, Austria. https://www.r-project.org/ (2016). 53. Laliberté, E. et al. Package 'FD'. Measuring functional diversity from multiple traits, and other tools for functional ecology (2014). 54. Khanaposhtani, M. G. et al. Effects of logged and unlogged forest patches on avifaunal diversity. Environ. Manag. 51, 750-758 (2013). 55. Tilman, D. et al. The influence of functional diversity and composition on ecosystem processes. Science 277, 1300-1302 (1997). 56. Edwards, F. A. et al. Impacts of logging and conversion of rainforest to oil palm on the functional diversity of birds in Sundaland. Ibis 155, 313-326 (2013). 57. Azeria, E. T. et al. Differential response of bird functional traits to post-fire salvage logging in a boreal forest ecosystem. Acta Oecol. 37, 220-229 (2011).

\section{Figures}

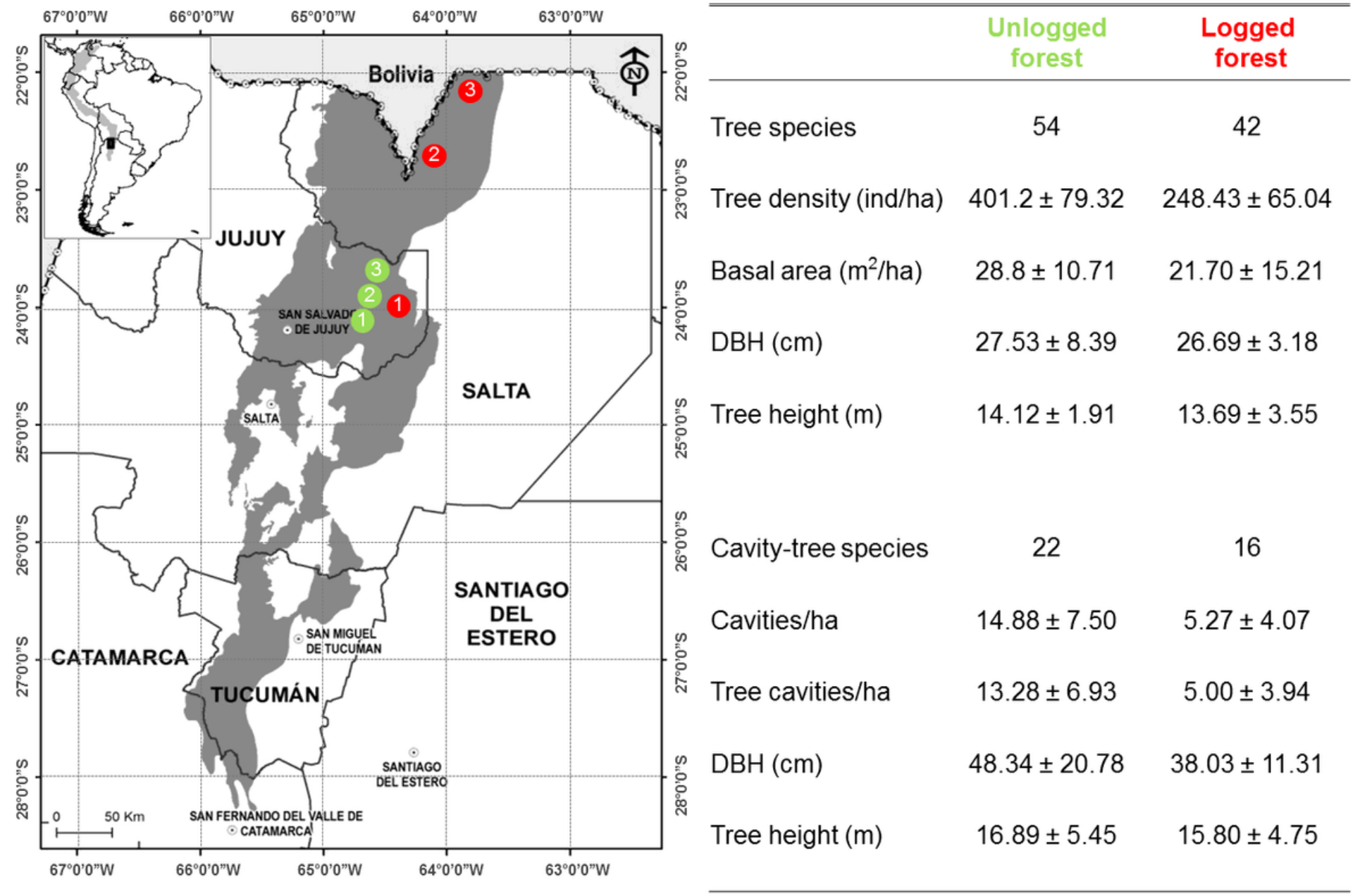

\section{Figure 1}

Location of the study sites in subtropical piedmont forests of northwestern Argentina: Unlogged (in green) and logged forest (in red). Total tree species and habitat variables measured are shown. 

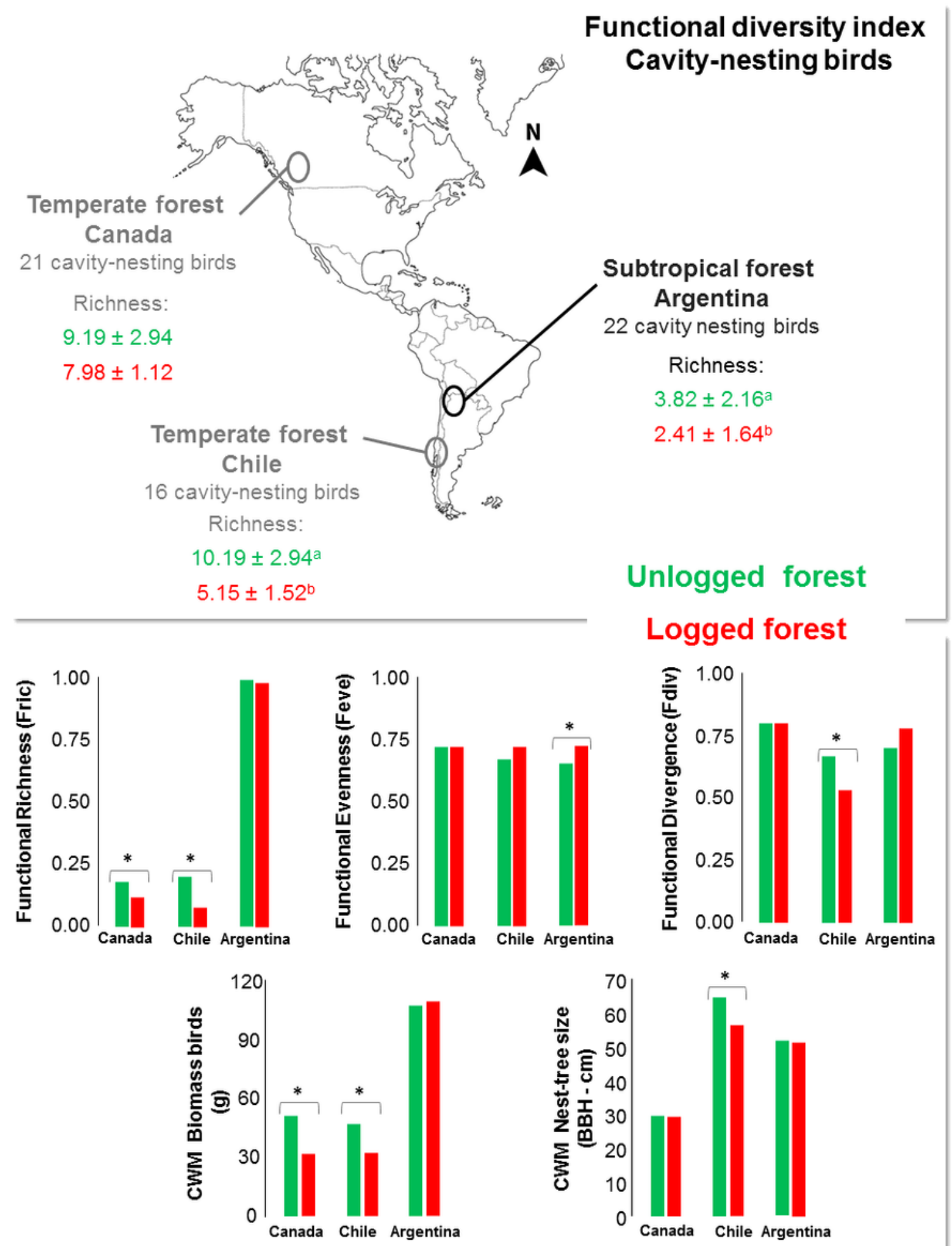

Figure 2

Functional richness and diversity in temperate American forests and Argentinian subtropical forests. Details on the number of bird species and richness found in each site (above): distinct letters indicate differences in the mean values between treatments. Functional diversity indexes measured in all sites (below) and significant differences in mean values $\left({ }^{*}\right)$ between treatments. 


\section{Supplementary Files}

This is a list of supplementary files associated with this preprint. Click to download.

- suplementarymaterial.pdf 